\title{
ANALISIS SOSIO-EKONOMI TERHADAP PRAKTEK PENANGANAN MUTU IKAN PELAGIS KECIL DI TEMPAT PELELANGAN IKAN BLANAKAN DAN PEKALONGAN
}

\author{
A.H. Purnomo*), Subaryono*), Suryanti"), dan E.S. Heruwati")
}

\begin{abstract}
ABSTRAK
Makalah ini didasarkan pada hasil penelitian yang dilaksanakan pada bulan Juli 2002, di dua lokasi penelitian, yaitu Blanakan (Jawa Barat) dan Pekalongan (Jawa Tengah), dengan maksud untuk mengetahui penyebab terjadinya susut pasca panen hasil pendaratan ikan pelagis kecil di kedua lokasi tersebut. Data yang dipergunakan untuk melakukan analisis dikumpulkan melalui wawancara dengan para pelaku pasar dan pejabat perikanan setempat. Informasi utama yang dapat dilaporkan dari hasil analisis adalah : Meskipun pelaku di setiap simpul dalam rantai penanganan telah menyadari hubungan antara praktek penanganan yang mereka lakukan dengan kualitas ikan yang dihasilkan, serta kaitannya dengan keuntungan potensial yang dapat mereka harapkan, beberapa faktor yaitu profitabilitas, resiko, teknis, dan faktor sosial budaya telah menyebabkan belum sempurnanya praktek penanganan dan berakibat pada terjadinya susut pasca panen (post harvest loss).
\end{abstract}

\section{ABSTRACT: Socio-Economic Analysis on Small Pelagic Fish Handling Practices at Blanakan and Pekalongan Fish Auction Centers.}

This paper is based on research activities carried out in July 2002, in two locations, i.e., Blanakan (West Java) and Pekalongan (Central Java). The main purpose of the research is to identify factors that have led to post-harvest losses of small pelagic fish landed at the observed locations. Data were collected through interviews with market players and fisheries officers at the locations. The primary result of the research is information that even though all players at every marketing node were aware of the relationship between handling practices and the fish quality as well as the potential profit, several factors, i.e., profitability, risk, technical, and socio cultural factors, had caused handling imperfectness, which thereafter led to post-harvest losses

KEYWORDS : $\quad$ socio economic, small pelagic, fish handling

\section{PENDAHULUAN}

Menurut definisinya (Morissey, 1988), susut pasca-panen perikanan (postharvest fishery losses) mencakup pengertian kehilangan/kerugian nutrisi dan atau ekonomis yang terjadi pada ikan sejak tahap paling awal, yaitu saat ikan diangkat dari media tumbuh/hidupnya (laut, kolam, dsb.). Praktek penanganan ikan segar yang diterapkan pada tahap-tahap awal rantai penanganan dan pemasaran berpotensi membawa implikasi yang luas terhadap kinerja industri perikanan.

Ditegaskan oleh Morissey (1988) bahwa penanganan pada tahap awal merupakan penentu bagi mutu dan daya simpan ikan; kerugian yang ditimbulkan akibat penanganan awal yang salah juga akan berpengaruh pada proses-proses penanganan lanjutan. Dampak negatif yang diakibatkan oleh kegagalan dalam pelaksanaan penanganan di atas kapal, tidak hanya terbatas pada kemungkinan berkurangnya pasokan bahan baku yang diperlukan oleh unit-unit usaha pengolahan, melainkan dapat meluas pada kerugian terhadap konsumen ,bahkan terkait dengan efisiensi sumberdaya. Di sisi konsumen, kerugian tersebut dapat berbentuk keterbatasan jumlah ikan segar maupun produk olahan yang bermutu baik yang dapat mereka konsumsi, atau dalam bentuk selisih harga yang diperlukan untuk mendapatkan ikan bermutu baik. Hasil kumulatif dari implikasi-implikasi tersebut tidak lain adalah sebuah bentuk inefisiensi pemanfaatan sumberdaya (Anderson and Anderson, 1988), karena sebagian potensi hasil atau nilai manfaat yang terkait dengan usaha eksploitasi sumberdaya terbuang secara cuma-cuma.

\footnotetext{
") Peneliti pada Pusat Riset Pengolahan Produk dan Sosial Ekonomi Kelautan dan Perikanan
} 
Susut hasil (product loss) perikanan Indonesia, yang berlangsung baik di lokasilokasi penangkapan maupun di tempat pendaratan, tidak dapat diabaikan. karena diperkirakan cukup besar kontribusinya terhadap kegagalan manajemen perikanan. Penanganan yang buruk ini semakin memperbesar inefisiensi sumberdaya yang diakibatkan oleh kapal-kapal traw/ penangkap udang, yang membuang sejumlah besar hasil tangkap yang dianggap bernilai ekonomis lebih rendah dibanding spesies targetnya (discarding) dan hanya mendaratkan hasil tangkap yang bernilai tinggi (high-grading) (Chasanah, 1999).

Khusus tentang susut hasil yang diakibatkan oleh penanganan yang kurang baik, informasi dari tempat-tempat pendaratan ikan oleh kapal-kapal purse seiner berdurasi layar sedang sekitar 7-14 hari dan panjang lebih dari 25 hari menyatakan bahwa susut hasil mencapai kisaran $29 \%$. Apabila jumlah ini dikalikan dengan rata-rata produksi ikan per tahun dari kapal purse seiner dari berbagai ukuran sebesar \pm 610.000 ton/tahun (Anonim, 2000b), maka potensi kerusakan adalah sebesar 200.000 ton/tahun. Angka ini cukup signifikan; misalnya, dengan ukuran sumbangan terhadap konsumsi ikan perkapita maka susut ini setara dengan kehilangan potensi peningkatan konsumsi ikan masyarakat Indonesia (populasi 200 juta) sebesar kurang lebih $1 \mathrm{~kg} / \mathrm{kapita} / \mathrm{tah} u n$.

Hasil-hasil penelitian terdahulu mengenai hal ini menunjukkan adanya peluang-peluang untuk memperbaiki keadaan tersebut diatas (Hansen, 1988). Misalnya, pemasangan palka berinsulasi dan penggunaan es dalam penanganan ikan di atas kapal maupun di tempat-tempat pendaratan telah memberikan solusi sampai batas tertentu. Namun demikian, kondisi lapangan mengindikasikan bahwa praktek penanganan secara baik tersebut masih dapat ditingkatkan lagi, sepanjang beberapa faktor yang menghambat selama ini dapat diatasi. Berkaitan dengan itu, penelitian ini dilaksanakan untuk memberikan perhatian khusus pada identifikasi faktorfaktor tersebut, berikut peluang-peluang yang berpotensi untuk mengatasinya.

Penelitian ini bertujuan untuk mengidentifikasi dan menganalisis faktor-faktor yang mempengaruhi praktek penanganan ikan pelagis kecil untuk menemukan peluang meminimalkan susut hasil produk perikanan.

\section{METODE}

Penelitian ini dilakukan dengan mengambil studi kasus di Blanakan dan Pekalongan dengan pertimbangan bahwa di kedua lokasi tersebut terdapat aktivitas pendaratan, pengolahan, dan pengiriman ikan pelagis kecil dengan intensitas yang tinggi. Di samping itu, masing-masing dipilih untuk mewakifi lokasilokasi pendaratan kapal-kapal mini purse seiner dan purse seiner berdurasi trip pendek (Blanakan) dan panjang (Pekalongan), karena masalah durasi trip diduga telah memunculkan masalah-masalah yang terkait dengan penanganan ikan.

Tinjauan permasalahan dan sintesis kesimpulan dalam penelitian ini dilakukan dengan menggunakan pendekatan sistem input-output. Dalam hal ini, diasumsikan bahwa mutu ikan dan produk-produknya merupakan suatu output dari suatu penanganan, yang besar-kecil atau baikburuknya tergantung pada ketersediaan sejumlah input dan dipengaruhi oleh berbagai faktor, yang dapat diklasifikasikan ke dalam faktor fisik/teknis dan sosial atau digolongkan ke dalam aspek internal dan eksternal. Termasuk input-input untuk menghasilkan output tersebut adalah berbagai perlakuan yang diterapkan terhadap ikan (input terkendali) dan cuaca atau iklim di wilayah dimana ikan tersebut berada (input tak terkendali). Adapun aspek internal yang mempengaruhi sistem tersebut adalah hal hal yang menyangkut biaya produksi, perhitungan untung-rugi, resiko usaha dan sebagainya, sedangkan yang termasuk aspek eksternal adalah antara lain ketersediaan saranaprasarana penunjang. Dengan mengetahui kondisi dari aspek-aspek yang terkait dengan sistem tersebut, analisis dalam penelitian ini dimaksudkan untuk mengidentifikasi peluang untuk memperbaiki output, dengan cara melakukan manipulasi pada input atau pun pada faktor-faktor yang berada dalam sistem.

Data yang dipergunakan untuk melakukan analisis dalam penelitian ini diperoleh melalui wawancara dengan para pelaku yang terlibat dalam rantai penanganan di dalam dan di sekitar lokasi penelitian. Responden yang diwawancarai adalah anak buah kapal, kapten kapal, pemilik kapal, pedagang pengumpul, petugas TPI (Tempat Pelelangan Ikan), dan Pejabat Dinas Perikanan Kabupaten/Kota. 


\section{HASIL DAN PEMBAHASAN}

\section{Kondisi Penanganan Ikan}

Dengan asumsi bahwa produsen-produsen ikan di lokasi penelitian berperilaku pasar secara rasional dan semua aspek lingkungan mendukung, dapat dipastikan bahwa produsen-produsen tersebut akan berusaha memaksimalkan keuntungan usahanya melalui tindakan-tindakan ekonomis tertentu, yaitu perlakuan-perlakuan terhadap ikan guna
Sebagaimana disebutkan di muka, faktorfaktor penting seperti pengetahuan pasar, kesadaran konsumen, masalah profitabilitas, resiko usaha, dan sarana penunjang, kesemuanya berpotensi mendorong terjadinya hal-hal tersebut.

\section{Profitabilitas}

Dari segi profitabilitas, sebenarnya hasil analisis sebagaimana tergambar pada Tabel 2 menunjukkan adanya peluang untuk

Tabel 1. Kondisi penanganan ikan pelagis kecil pada kelompok-kelompok pelaku pasar di Pekalongan dan Blanakan

Table 1. Handling Condition of small pelagic fish at market player groups in Pekalongan and Blakanan

\begin{tabular}{|c|c|c|c|}
\hline $\begin{array}{l}\text { Lokasi } \\
\text { Location }\end{array}$ & $\begin{array}{l}\text { Pelaku pasar } \\
\text { Market player }\end{array}$ & $\begin{array}{l}\text { Kondisi perlakuan" } \\
\text { Handling condition }\end{array}$ & $\begin{array}{c}\text { Keterangan } \\
\text { Remark }\end{array}$ \\
\hline Pekalongan & $\begin{array}{l}\text { Kapten \& ABK } \\
\text { Boat Crews } \\
\text { Pengumpul } \\
\text { Middlemen } \\
\text { Pengolah } \\
\text { Processors }\end{array}$ & $\begin{array}{l}\text { Kurang/Bad } \\
\text { Baik/Good }\end{array}$ & $\begin{array}{l}\text { Kondisi perlakuan yang kurang baik di } \\
\text { TPI Pekalongan terutama terjadi pada } \\
\text { kapal-kapal purse seiner besar. } \\
\text { (Bad handling condition at the } \\
\text { Pekalongan Auction Center occurs mainly } \\
\text { on big purse seiners). }\end{array}$ \\
\hline Blanakan & $\begin{array}{l}\text { Kapten \& ABK } \\
\text { Boat Crews } \\
\text { Pengumpul } \\
\text { Middlemen } \\
\text { Pengolah } \\
\text { Processors }\end{array}$ & $\begin{array}{l}\text { Baik/Good } \\
\text { Baik/Good }\end{array}$ & $\begin{array}{l}\text { Meskipun tidak dapat dikatakan } \\
\text { sempurna, kondisi penanganan di } \\
\text { Blanakan pada umumnya dapat } \\
\text { dikategorikan cukup memadai. (Although } \\
\text { may not be categorized as perfect, } \\
\text { handling condition at Blanakan Auction } \\
\text { Center can be classified as sufficiently } \\
\text { performed). }\end{array}$ \\
\hline
\end{tabular}

- 'Baik'/'Good'= dilakukan sesuai keperluan, misalnya menyimpan dalam wadah berinsulasi dengan jumlah es yang cukup/ to be done as of required, for example treatment in the insulated container with enough ice.

- 'Kurang'/ 'Bad'=dilakukan kurang dari yang seharusnyal to be done less than required

mempertahankan kesegaran dengan tujuan memaksimalkan harga jualnya.

Dari pengamatan langsung dan wawancara yang dilakukan dengan para pelaku pasar di sekitar TPI Blanakan dan TPI Pekalongan, diperoleh hasil bahwa penanganan yang cukup baik telah dilaksanakan pada sebagian simpul-simpul lanjutan dari rantai penanganan. Penyebab penurunan mutu yang cukup signifikan terjadi pada simpul awal, yaitu pada saat ikan berada di atas kapal. Akibatnya, ketersediaan ikan yang bermutu baik di wilayah tersebut kurang dari potensi maksimalnya. Kondisi penanganan ikan pada masing-masing kelompok pelaku pasar di kedua lokasi penelitian dapat dilihat pada Tabel 1.

Satu intuisi yang dapat ditarik dari informasi dalam Tabel 1 adalah bahwa suatu analisis/tinjauan yang lebih mendalam dengan fokus pada simpul tersebut perlu dilakukan. meningkatkan keuntungan bagi anak buah kapal (ABK) dan kaptennya melalui perbaikan cara penanganan di atas kapal purse seiner. Dengan mengubah praktek penanganan dari menggarami seluruh ikan hasil tangkapan ke pengesan separuh dari ikan-ikan tersebut, ABK dan kapten berpeluang untuk meningkatkan potensi keuntungan maksimal sebesar Rp 60 juta/trip ${ }^{2)}$. Kenaikan potensi keuntungan tersebut bahkan dapat dinaikkan lagi menjadi Rp 75 juta/trip ${ }^{3)}$ apabila perlakuan pengesan diterapkan pada seluruh hasil tangkapan.

\section{Resiko Usaha}

Meskipun memberikan potensi margin keuntungan positif yang cukup signifikan, perbaikan cara penanganan dengan menggunaan es sebagai media pengawet 
terkait dengan resiko kerugian bagi ABK maupun kaptennya. Seperti terlihat pada Tabel 2, dengan menerapkan perlakuan penggaraman terhadap seluruh ikan hasil
Pemasukan faktor resiko sebenarnya tidak hanya dilakukan oleh nelayan pada kapalkapal purse seiner, melainkan juga nelayan pada kapal-kapal mini purse seiner. Dengan

Tabel 2. Analisis parsial penggunaan tiga cara penanganan ikan pelagis kecil di atas kapal ${ }^{1)}$

Table 2. Partial analysis for the use of three on-board handling methods on small pelagic fish

\begin{tabular}{lrrr}
\hline & \multicolumn{3}{c}{ Cara penanganan (Handling method) } \\
\cline { 2 - 4 } & $\begin{array}{l}\mathbf{1 0 0 \%} \text { es (100\% ice) } \\
\text { Juta Rp (Million Rp) }\end{array}$ & $\begin{array}{c}\mathbf{5 0 \%} \text { Juta Rp (M0\% ice) } \\
\text { (Million Rp) }\end{array}$ & $\begin{array}{c}\text { 100\% Garam (100\% salt) } \\
\text { Juta Rp (Million Rp) }\end{array}$ \\
\hline Biaya/Cost & 30 & 10 & 0 \\
- Es/ice & 0 & 20 & 40 \\
- Garam/salt & & & $160-200$ \\
Penerimaan/revenue & 0 & $100-200$ & 0 \\
- Ikan Asin/salted fish & $90-250$ & $20-50$ & $7-10$ \\
- Ikan Segar/fresh fish & $10-25$ & $4-25$ & $127-170$ \\
- Ikan Es/chilled fish & $70-245$ & $94-230$ & \\
Keuntungan/Net Benefit & & &
\end{tabular}

tangkapan, keuntungan minimal (keuntungan yang dihitung dengan mengabaikan biayabiaya di luar biaya penanganan di atas kapal) yang diperoleh adalah Rp 127 juta/trip, sedangkan apabila penggaraman hanya dilakukan terhadap separuh dari hasil tangkapan, keuntungan minimal tersebut turun sebesar Rp 31 juta menjadi Rp 94 juta. Dengan perlakuan pengesan terhadap seluruh hasil tangkapan, penurunan keuntungan dapat mencapai Rp 57 juta/trip. Penurunan keuntungan yang terjadi pada praktek penanganan menggunakan es tersebut terkait dengan durasi trip kapal-kapal purse seiner. Pengesan berpotensi untuk menghasilkan ikan dengan harga jual yang tinggi yaitu pada saat durasi trip tidak terlalu lama, akan tetapi sebaliknya, dapat menyebabkan turunnya harga secara drastis akibat tidak mampunya es untuk menahan kerusakan ikan yang berada di atas kapal dalam waktu yang terlalu lama. Di sisi lain, penggaraman memberikan kisaran mutu yang relatif sempit sehingga fluktuasi harga dapat diminimalkan. Gambaran tentang resiko penggunaan es tersebut akan menjadi lebih signifikan apabila analisis di atas memperhitungkan biaya-biaya di luar biaya penanganan ikan di atas kapal. perhitungan bahwa 10 balok es telah cukup untuk mengawetkan ikan sebanyak hasil tangkapan minimal, sebagian besar nelayan purse seiner membawa es tidak lebih dari 10 balok, meskipun jumlah ini tidak cukup untuk mengawetkan ikan untuk hasil tangkapan maksimal. Namun demikian, karena armada mini purse seiner pada umumnya mempunyai durasi trip tidak lebih dari satu hari, kemunduran mutu ikan akibat kekurangan es tidak terlalu signifikan.

\section{Sosial/budaya}

Hasil wawancara menunjukkan bahwa, menyadari keuntungan potensi yang dapat diperoleh, para pemilik kapal cenderung untuk memilih penanganan ikan menggunakan es. Pemilik-pemilik tersebut pada umumnya sangat menganjurkan $A B K$ dan kapten kapal untuk membawa es dalam jumlah yang cukup. Akan tetapi, sejauh ini, anjuran yang disampaikan oleh para pemilik kepada para ABK dan kapten kapal tidak sepenuhnya berhasil.

Dari sudut sosial, hal tersebut dapat dijelaskan dengan analisis yang menyangkut

\footnotetext{
1) Tabel 2 dimaksudkan untuk memberikan angka keuntungan relatif yang terkait dengan penerapan tiga jenis perlakuan di atas kapal; untuk itu, keuntungan absolut yang memperhitungkan biaya perbekalan (Rp 18 juta pertrip) dan biaya-biaya relevan lainnya, tidak ditampilkan dalam tabel tersebut

2) Rp 230 juta (pengesan 50\%) minus Rp 170 juta (pengesan $0 \%$ )

${ }^{3)}$ Rp 245 juta (pengesan 100\%) minus Rp 170 juta (pengesan 0\%)
} 
faktor sosial, terutama yang terkait dengan tingkat pendapatan dan ketergantungan nelayan pada usaha penangkapan di atas kapal dimana mereka bekerja. Nelayan memperoleh imbalan yang rendah dibanding pemilik dan mempunyai ketergantungan yang tinggi terhadap usaha penangkapan. Dengan demikian, penurunan hasil pada suatu trip akan besar artinya bagi para nelayan tersebut. Sebaliknya, pemilik pada umumnya memiliki beberapa alternatif sumber penghasilan, baik dalam bidang perikanan (dalam bentuk kepemilikan kapal-kapal lebih dari satu) maupun usaha di luar bidang perikanan. Dengan demikian, pengaruh penurunan keuntungan yang terjadi pada salah satu kapal pada satu atau beberapa trip, terhadap penghasilan total tidak terlalu signifikan. Implikasi dari adanya faktor ini adalah bahwa ABK dan kapten kapal akan cenderung bersifat menghindari resiko (risk averse) sedangkan pemilik cenderung lebih berani menanggung resiko (risk taker).

Menyangkut sisi budaya, satu hal yang diidentifikasi sebagai faktor yang dapat mempengaruhi tingkat mutu produk yang dihasilkan oleh kapal-kapal purse seiner di lokasi penelitiaan adalah keyakinan sebagian nelayan bahwa ketika mereka menemukan kawanan ikan dalam jumlah besar, sebanyak mungkin ikan harus diangkat sedangkan hasil tangkapan sebelumnya yang telah ada di atas kapal pantang untuk dibuang, betapapun telah mengalami kemunduran mutu. Akibatnya, nelayan tetap harus membawa pulang (mendaratkan) ikan yang berkualitas rendah meskipun memiliki kesempatan untuk mendapatkan hasil dengan mutu yang lebih baik. Terlebih lagi, penampungan ikan tangkapan terakhir tersebut sering dilakukan dengan mengorbankan ketersediaan es (membuang es untuk menaikkan daya tampung ruang palka untuk ikan), sehingga secara umum hasil tangkapan menjadi cepat mengalami kemunduran.

\section{Faktor Teknis \& Pengetahuan}

Menurut hasil survai di lokasi penelitian, beberapa faktor teknis yang penting yaitu ketersediaan sarana, prasarana, penguasaan teknologi, tidak menjadi hambatan bagi terlaksananya penanganan di atas kapal secara lebih baik. Bahan utama untuk penanganan di atas kapal, yaitu balok-balok es, tersedia dengan cukup. Wawancara dengan para nelayan, pemilik, maupun para pedagang pengumpul, menunjukkan bahwa balok es dapat diperoleh dalam jumlah yang mencukupi kebutuhan mereka dalam jumlah harga yang terjangkau. Hal ini didukung pula oleh data menyangkut kapasitas produksi es di lokasi penelitian. Di Pekalongan, terdapat 8 pabrik es dengan kapasitas total sebesar 880 ton/hari (Anonim, 2000a) sedang di sekitar Blanakan, kapasitas produksi es perhari adalah 84 ton (Anonim, 2001). Jumlah ini cukup untuk melaksanakan pengesan terhadap hasil perikanan yang didaratkan di masing-masing lokasi tersebut.

Dari sisi penguasaan teknologi oleh pelaku pasar di lokasi penelitian, pengesan ikan tidak merupakan masalah yang signifikan. Meskipun ada variasi dalam prakteknya, para pelaku pasar pada umumnya telah memahami teknik-teknik pengesan yang benar. Untuk insulasi pada badan kapal misalnya, cara-cara pembuatannya telah dikuasai oleh pekerjapekerja lokal. Dengan demikian, sebagaimana dinyatakan oleh para responden, pertimbangan ekonomi merupakan satu-satunya faktor yang menentukan dipakai atau tidaknya insulasi. Sebagai catatan, biaya pengecoran insulasi berukuran $4 \times 4 \times 1 \frac{11}{2} \mathrm{~m}^{3}$ untuk kapal mini purse seiner adalah Rp 8 juta; bagi sebagian besar kapal dengan durasi laut kurang dari satu hari seperti halnya mini purse seiner, investasi tersebut merupakan bentuk inefisiensi karena penurunan mutu ikan dalam jangka itu tidak terlalu besar. Berdasarkan pengamatan nelayan, 10 balok es tanpa palka berinsulasi telah cukup untuk mempertahankan kesegaran 3 ton ikan hasil tangkapan kapal-kapal mini purse seiner.

Pengetahuan tentang segala resiko-resiko teknis maupun ekonomis yang akan terjadi dengan penerapan cara penanganan tertentu pada umumnya telah dipahami, baik oleh pelaku pasar. Misalnya, kerusakan $10 \%$ ikan, yang akan terjadi akibat benturan fisik antara ikan dengan bongkah-bongkah es yang berlangsung pada penangkapan di musim barat; $40 \%$ ikan bermutu rendah (BS) apabila kapal mini purse seiner hanya menyediakan 10 balok es dan menangkap ikan sampai batas kapasitas maksimalnya. Pengetahuan tentang resiko ekonomis dapat ditunjukkan oleh adanya pemahaman yang sama di antara setiap individu pelaku pasar, termasuk konsumen, tentang kondisi mutu ikan dan cara-cara pengukurannya, serta kisarankisaran harga yang berlaku untuk masingmasing kondisi mutu. 


\section{Perumusan Solusi Alternatif}

Dalam usaha perikanan tangkap, terutama di laut, peran faktor keberuntungan cukup signifikan. Hal ini secara naluriah berdampak pada perilaku nelayan yang berkecenderungan untuk menangkap ikan sebanyak mungkin pada saat kesempatan untuk itu tiba (misalnya pada saat nelayan menjumpai kawanan ikan dalam jumlah besar).

Di lain pihak, menangkap ikan dalam jumlah atau waktu melebihi kapasitas kapal untuk melakukan upaya pengawetan akan menimbulkan kerugian yang terkait dengan susut hasil. Tanpa adanya penanganan khusus, segera setelah proses pengangkatan dari media hidupnya, ikan akan segera mengalami proses pembusukan. Salah satu cara penanganan yang banyak dilakukan untuk menghambat proses pembusukan adalah aplikasi suhu rendah dengan menambahkan es ${ }^{4}$ pada tumpukan ikan yang tertangkap. Di sisi teknis, ada beberapa hal yang dapat menjadi kendala dalam usaha menekan laju kerusakan ikan melalui cara pengesan, antara lain: kemampuan kapal menahan beban dan menyediakan ruang untuk menampung es. Dari sudut pandang biologi, satu hal yang harus diingat adalah bahwa ikan sudah akan turun nilai komersialnya bila disimpan dalam es selama lebih dari 10 hari, meski bagaimana pun bagusnya cara penanganannya (Wheaton dan Lawson, 1985).

Tinjauan teoritis dan berbagai fakta di lapangan sebagaimana telah diungkapkan di atas, menyiratkan bahwa kepada nelayan, khususnya para nakhoda yang banyak berperan dalam menentukan durasi trip, perlu diberikan alternatif lain yang memungkinkan memperbesar potensi keuntungan dengan resiko kerugian minimal. Disamping itu, perlu pula ditingkatkan pemahaman bahwa menangkap ikan dalam jumlah dan waktu yang melebihi batas optimal berpotensi menurunkan keuntungan jangka panjang meskipun ada kemungkinan memberikan keuntungan sesaat. Keuntungan sesaat misalnya dapat dihubungkan dengan besarnya volume produksi ${ }^{5}$ yang lebih besar. Sementara itu, kerugian jangka panjang terkait dengan tersia-siakannya ${ }^{6 /}$ sumberdaya karena tertangkap tetapi tidak termanfaatkan akibat terjadinya kerusakan. Dengan kata lain, hal ini merupakan tindakan yang merugikan sumber daya alam, usaha nelayan, disamping juga kepentingan calon konsumen.

Untuk kapal berukuran besar, salah satu alternatif yang berpotensi untuk dipertimbangkan adalah penerapan teknologi refrigerasi di atas kapal. Dengan teknologi ini, daya awet ikan dapat diperpanjang hingga lebih dari satu bulan, cukup untuk mengatasi kendala lamanya periode layar kapal-kapal besar seperti purse seiner. Dengan demikian, tinjauan lebih mendalam melalui kegiatan penelitian yang menyangkut aspek teknis dan sosio-ekonomis tentang hal ini menjadi relevan untuk dilakukan pada saat ini. Untuk kapal berukuran kecil, yang pada umumnya berdurasi layar pendek, alternatif ini tidak dapat dan tidak perlu dipertimbangkan. Tidak dapat dipertimbangkan karena kemungkinan besar biaya yang dikeluarkan untuk itu akan terlalu besar dibanding dengan kapasitas produksi dari kapal-kapal tersebut; tidak perlu dipertimbangkan karena, sebagaimana telah disebutkan di muka, teknik pengesan masih merupakan alternatif yang cukup baik.

Observasi lapangan yang dilakukan melalui kegiatan penelitian ini juga mengindikasikan bahwa alternatif lain yang dapat dipertimbangkan untuk memperkecil dampak negatif dari kerusakan ikan adalah pengembangan industri tepung ikan. Fakta di lapangan menunjukkan bahwa ketersediaan ikan dengan harga yang relatif rendah (karena tidak layak konsumsi) telah dimanfaatkan oleh pengolah tepung ikan di lokasi-lokasi penelitian. Para pengusaha tepung ikan tersebut pada umumnya telah mempunyai saluran pemasaran yang mantap. Dengan harga tepung ikan Rp 2900,-/kg, harga bahan baku (ikan) yang layak bagi pengusaha tersebut adalah $\mathrm{Rp} 400,-/ \mathrm{kg}$. Harga ikan tolakan (BS) yang berlaku di lokasi penelitian

\footnotetext{
4) Idealnya, berat es yang ditambahkan tidak kurang dari berat ikan yang diawetkan

5) Hal ini terjadi apabila pengaruh preningkatan produksi terhadap keuntungan lebih besar dibanding pengaruh penurunan harga per satuan yang diakibatkan oleh kerusakan ikan.

6) Dalam perikanan tangkap, ikan merupakan output sekaligus input; besarnya output (tangkapan) pada suatu periode akan mempengaruhi input (dalam bentuk spawners), dan dengan demikian mempengaruhi tingkat produksi pada periode-periode berikutnya. Karena itu, kerusakan ikan yang tertangkap merupakan kerugian yang murni karena tidak hanya tidak hanya berarti hilangnya kesempatan untuk dikonsumsi, akan tetapi juga menurunkan peluang peningkatan hasil tangkapan di masa yang akan datang.
} 
adalah Rp.400,- - Rp.600,-/kg. Dalam situasi dimana harga bahan baku melebihi harga kelayakan usaha, penepung ikan memiliki jalan keluar berupa penggunaan campuran dalam bentuk limbah dari produsen ikan disiangi (dressed fish). Ketersediaan bahan baku yang murah merupakan satu hal yang memberikan solusi untuk masalah kelayakan usaha bagi para pengolah tepung ikan tersebut. Pelajaran yang dapat ditarik dari fakta ini adalah bahwa susut pasca panen yang telah terjadi pada tahap awal (akibat penanganan di atas kapal yang kurang baik), dapat diminimalkan melaui penciptaan nilai tambah pada proses pasca panen tahap lanjut seperti yang terjadi pada usaha penepungan ikan.

Dalam kaitannya dengan usaha penepungan ikan di lokasi penelitian, salah satu hal yang dapat dilakukan untuk mendukung dan meningkatkan kinerja para pengusaha adalah perbaikan mekanisme pengumpulan bahan baku. Salah satu contoh yang dapat diidentifikasi selama kegiatan penelitian ini adalah pengumpulan limbah dari produsen ikan telah disiangi (dressed fish). Peningkatan kinerja dapat pula dilakukan melalui penerapan teknologi tepat-guna yang dapat diadopsi oleh pengolah untuk meningkatkan kualitas produknya, misalnya teknologi yang memungkinkan pencapaian kadar protein minimal seperti yang dipersyaratkan oleh konsumen. Meskipun usaha-usaha perbaikan tersebut tidak terkait langsung dengan masalah susut hasil akibat penanganan buruk di atas kapal, peningkatan kinerja penepung ikan yang diakibatkan olehnya akan berdampak pada keberlanjutan usaha penepungan ikan, yang pada gilirannya akan memungkinkan keberlanjutan pemanfaatan hasil tangkapan yang rusak.

\section{KESIMPULAN}

Hasil analisis menunjukkan bahwa meskipun pelaku di setiap simpul dalam rantai penanganan telah menyadari hubungan antara praktek penanganan yang mereka lakukan dengan kualitas ikan yang dihasilkan, serta kaitannya dengan keuntungan potensial yang dapat mereka harapkan, ada beberapa faktor yang telah menyebabkan belum sempurnanya praktek penanganan dan berakibat pada terjadinya susut pasca panen (post harvest loss). Di antara faktor-faktor yang saling terkait dan mempengaruhi pelaku pasar dalam menentukan cara penanganan ikan di lokasi penelitian adalah profitabilitas, resiko, teknis, dan faktor sosial budaya.

Kasus di kedua lokasi penelitian menunjukkan bahwa kesiapan teknis dan potensi keuntungan bukan merupakan jaminan bagi dipilihnya cara-cara penanganan yang lebih baik. Dicontohkan dalam penelitian ini misalnya, meskipun pengesan memungkinkan ditekannya susut hasil secara lebih baik dan diperolehnya keuntungan maksimal, pertimbangan resiko menyebabkan anak buah kapal cenderung memilih cara penanganan alternatif, yaitu penggaraman, yang meskipun hanya memberikan keuntungan minimal, memiliki resiko kerugian yang lebih kecil.

Beberapa alternatif dapat dipertimbangkan untuk mengatasi masalah yang ada; meskipun tinjauan yang lebih mendalam dari berbagai aspek masih diperlukan. Dari sudut pandang keilmiahan, hal ini dapat dipandang sebagai petunjuk tentang adanya grey area, yang memberikan gambaran tentang salah satu topik penelitian penting yang perlu dilakukan untuk saat ini. Dari sudut pandang praktis/aplikasi, hal ini menunjukkan perlunya peningkatan pemahaman di kalangan nelayan untuk mempertimbangkan alternatif cara penanganan lain yang dapat meningkatkan keuntungan jangka pendek mereka tanpa mengorbankan masa depan usahanya dan kelestarian sumberdaya.

\section{DAFTAR PUSTAKA}

Anderson, J.L. and Anderson, J.G. 1988. economics and seafood quality. In Morissey, T. (ed.). Postharvest Fishery Losses. Proceedings of an International Workshop Held April 12-16 1987 at The University of Rhode Island, Kingston, RI. ICMRD, Kingston, RI.

Anonim. 2001. Penelitian Mutu Ikan Pelagis Kecil Untuk Konsumsi dan Bahan Baku Industri. Laporan Teknis Tahun Anggaran 2001. Pusat Riset Pengolahan Produk dan Sosial Ekonomi Kelautan dan Perikanan.

Anonim. 2000a. Perikanan Jawa Tengah Dalam Angka. Dinas Kelautan dan Perikanan Propinsi Jawa Tengah.

Anonim. 2000b. Statistik Perikanan Tangkap Indonesia. Departemen Kelautan dan Perikanan-Direktorat Jenderal Perikanan Tangkap, Jakarta.

Chasanah, E. 1999. By-catch utilization in Indonesia. In Clucas, I. and Teutscher, F (eds.) By-catch Utilization in Tropical Fisheries. Report and Proceedings of FAO/DFID Expert 
Consultation on By-catch Utilization in Tropical Fisheries. FAO/DFID Beijing, China.

Hansen, P. 1988. The reduction of postharvest losses by improved catch handling and storage at sea. In Morissey, T. (ed.). Postharvest Fishery Losses. Proceedings of an International Workshop Held April 12-16 1987 at The University of Rhode Island, Kingston, RI. ICMRD, Kingston, RI.
Morissey, T. 1988. postharvest fishery losses: A definition of Terms. In Morissey, T. (ed.). Postharvest Fishery Losses. Proceedings of an International Workshop Held April 12-16 1987 at The University of Rhode Island, Kingston, RI. ICMRD, Kingston, RI.

Wheaton, F.W. and Lawson, T.B. 1985. Handling at harvest. In John Wiley \& Sons Publ. Processing Aquatic Food Products. Canada, p. 107-118. 